\title{
ORCONECTES LIMOSUS COLONISES NEW AREAS FAST ALONG THE DANUBE IN HUNGARY
}

\author{
M. PUKY (1) AND P. SCHÁD (2)
}

(1) Hungarian Danube Research Station of the Institute of Ecology and Botany, Hungarian Academy of Sciences, 2131 GÖD, Jávorka S. u. 14, Hungary.

E-mail: h7949puk@ella.hu

(2) Varangy Akciócsoport Egyesület, 1013 Budapest, Pauler u. 19, Hungary. E-mail: schad@freemail.hu

Reçu le 16 juin 2005

Accepté le 12 décembre 2005

Received June 21, 2005

Accepted December 12, 2005

\begin{abstract}
Introduced species are one of the most important anthropogenic impacts on freshwater ecosystems with many direct and indirect effects on native taxa. Among other invasive groups, such as plants, mussels and fish, several alien Decapoda species have also spread successfully in Europe in the last 110 years. In Hungary three native (Astacus astacus, Astacus leptodactylus, Austropotamobius torrentium) and three alien Decapoda species, namely Orconectes limosus, Pacifastacus leniusculus and Eriocheir sinensis are known to be present. O. limosus, which had been tried for use in crayfish farming in the 1950s, was the first to occur in the country's natural waters. Initially it was found in the Danube at river km 1,653 at Budapest in 1985. Since then, it has been spreading fast and populations have reached high abundances. By 1998, it was already in the Gemenc section of the river colonising five $50 \mathrm{~km} \times 50 \mathrm{~km}$ UTM squares. In the early 2000s it was also found at Mohács (and further downstream in Croatia), in canals in the Great Hungarian Plain and in the River Ipoly, which added three new $50 \mathrm{~km} \times 50 \mathrm{~km}$ UTM squares to its previously known distribution area in the Carpathian Basin. On the basis of the available records from the past 20 years, the downstream colonisation speed of this decapod was calculated to be more than $13 \mathrm{~km} \mathrm{yr}^{-1}$, but if its presence at Kopácsi rét/Kopacki rit in Croatia is also taken into consideration, it is over $16 \mathrm{~km} \mathrm{yr}^{-1}$. It is unknown, however, how much this process was helped by deliberate introductions, if at all. Besides the main watercourse of Hungary, O. limosus is also common in its lowland tributaries and spreading towards Lake Balaton along the Sió canal. However, it has not been recorded entering mountain streams in the Danube Bend, where $A$. torrentium lives, which is important for the conservation of that native species. If $O$. limosus spreads with the same speed and distribution pattern in the Carpathian Basin, it may colonise large rivers such as the River Tisza, their lowland tributaries and canals in the near future. Based on the present situation, O. limosus is likely to threaten $A$. astacus populations especially in the southern part of Transdanubia, perhaps leading to the elimination of some populations, but less likely to affect $A$. torrentium living in the mountains of the Danube Bend.
\end{abstract}

Key-words: crayfish, Orconectes limosus, alien species, Hungary, distribution, conservation. 


\section{ORCONECTES LIMOSUS COLONISE DE NOUVELLES ZONES LE LONG DU DANUBE EN HONGRIE}

\section{RÉSUMÉ}

Les espèces introduites représentent un des impacts anthropiques les plus importants au niveau des écosystèmes d'eau douce avec beaucoup d'effets directs ou indirects sur les espèces natives. Parmi d'autres groupes invasifs, tels que les plantes, les moules et les poissons, plusieurs espèces étrangères de décapodes se sont aussi répandues avec succès en Europe pendant les 110 dernières années écoulées. En Hongrie, trois espèces natives (Astacus astacus, Astacus leptodactylus, Austropotamobius torrentium) et trois espèces étrangères (Orconectes limosus, Pacifastacus leniusculus et Eriocheir sinensis) de décapodes sont connues. O. limosus, qui a fait l'objet d'une tentative d'élevage dans les années 50 , fut la première à atteindre les eaux naturelles. A l'origine, elle fut trouvée dans le Danube au km 1,653 à Budapest en 1985. Depuis elle s'est répandue rapidement et les populations sont très abondantes. En 1998, elle était présente dans la section de Gemenc de la rivière en colonisant cinq carrés UTM de $50 \mathrm{~km} \times 50 \mathrm{~km}$. Dès les années 2000, elle a été trouvée également à Mohács (puis en aval en Croatie), en atteignant ainsi son aire de distribution au niveau du Bassin des Carpates. Sur la base des données disponibles ces 20 dernières années, la colonisation rapide de ce décapode a été évaluée à plus de $13 \mathrm{~km}$ par an, mais si on tient compte également de sa présence à Kopácsi rét/Kopacki rit en Croatie, elle est alors estimée à plus de $16 \mathrm{~km}$ par an. Par contre, il n'est pas connu si cette progression a été favorisée par des introductions délibérées. A part dans les cours d'eau principaux de Hongrie, $O$. limosus est aussi commune dans les petits cours d'eau et s'est aussi répandue vers le lac Balaton le long du canal Sió. Cependant elle n'a pas été signalée dans les cours d'eau de montagne dans le Danube Bend, où $A$. torrentium vit, ce qui est important pour la sauvegarde de cette espèce indigène. Si $O$. limosus se répandait avec la même vitesse et mode de distribution dans le bassin des Carpates, à moyen terme, elle coloniserait de grands cours d'eau tels que la rivière Tisza, ses petits affluents et les canaux. Au vu de la situation actuelle, O. limosus pourrait donc plutôt menacer les populations d'A. astacus, en particulier dans la partie sud du Transdanube, que celles d'A. torrentium qui vivent dans les zones montagneuses du Danube.

Mots-clés: écrevisses, Orconectes limosus, espèces introduites, Hongrie, distribution, conservation.

\section{INTRODUCTION}

Introduced species are one of the most important anthropogenic impacts on freshwater ecosystems with many direct and indirect effects on native taxa. They can cause degradation of natural habitats, alter species assemblages and trophic structure, displace or decimate native species (ALDRIDGE et al., 2004; GRATTON and DENNO, 2005) depending on the number of simultaneous negative interactions such as competition and predation (MILLS et al., 2004). Among other invasive groups, such as plants, mussels and fish, crayfish have particularly important ecological impacts on aquatic ecosystems. However, they were often introduced outside their native ranges, either by deliberate stocking or even by bait bucket releases (HOBBS et al., 1989).

In the last 110 years several alien decapod species have spread successfully in Europe. In Hungary three native and three alien Decapoda species, namely Orconectes limosus, Pacifastacus leniusculus and Eriocheir sinensis are known to be present (PUKY et al., 2005). The spread of all these species accelerated at the turn of the century, Eriocheir sinensis, for example, which had first been found in the Hungarian Danube stretch in 2003 at Budapest, was also detected in February, 2004 from the same river but nearly $200 \mathrm{~km}$ downstream, at river $\mathrm{km} \mathrm{1,437}$ at Kölked. This new locality corresponds 
well to the estimation of CZERNIEJEWSKI and FILIPIAK (2001), who found the average migration speed of young crabs to vary between 1 and $3 \mathrm{~km}^{\text {day }}{ }^{-1}$ depending on the conditions, as well as with the fact that this species has recently been found in the River Danube both upstream and downstream of Hungary (PAUNOVIC et al., 2004; RABITCH and SCHIEMER, 2003).

O. limosus is a North American crayfish species native to the eastern part of the continent. Following its introduction to Europe at the end of the 19th century to compensate for the strong decline of Astacus astacus caused by crayfish plague, it colonised areas from the Pyrenees and Italy north to England and Belorussia (HOLDICH, 2002). This species may strongly influence other aquatic organisms (see e.g. CALLAGHAN and KARLSON, 2002) and evidence has also accumulated that it also affects native European crayfish by spreading the crayfish plague, which is a significant threat to European native species causing disappearance and decline till today (for a description of recent crayfish plague outbreaks and the role of $O$. limosus within the process see for example KOZUBIKOVÁ et al., 2005). Adversely, in North America, its New England populations are threatened by another closely related invasive crayfish species, Orconectes rusticus (KLOCKER and STRAYER, 2004).

This article describes the spread of $O$. limosus in Hungary together with its possible consequences.

\section{MATERIAL AND METHODS}

The distribution of $O$. limosus was investigated in several sections of the Danube. Active diurnal searches by turning stones and checking holes and trapping were used to prove the presence of the species. The occasional findings of dead crayfish on the banks were also taken into consideration (PUKY, 2000, 2004). Besides crayfish-oriented surveys, valuable observations or collections were also made during the study trips of the Hungarian Danube Research Station staff along the River Danube or its backwaters. Several crayfish specialists were also interviewed and other experts (e.g. ichthyologists) were also contacted to incorporate their observations into the database together with the available literature. In those investigations crayfish were caught by hand, netting, diving and dredging and also by electro fishing during ichthyological surveys (CSÁNYI et al., 2002; KOVÁCS et al., 2005; NESEMANN et al., 1995).

To provide reliable data, doubtful records were not included in the compiled database, similarly to other European countries such as Poland (ŚMIETANA, 2004). However, these sites should be checked in the future, as it is possible they might provide valuable additional information.

Data are presented here in a graphical format, which shows the distribution area of the species in $50 \mathrm{~km} \times 50 \mathrm{~km}$ UTM square units. To show the spreading of $O$. limosus over time, data were summarised by decades starting from the 1950s, when the species was introduced to Hungary for farming (THURÁNSZKY, 1960).

\section{RESULTS AND DISCUSSION}

The distribution of O. limosus in Hungary between 1950 and 2004 can be seen in Figure 1. This species was introduced to Hungary from Germany in the late 1950s for farming, when approximately 12,000 individuals were imported (THURÁNSZKY, 1960). That venture was not successful and no records existed for Hungary for the 1960s and 1970s. In natural waters the first individuals were recorded in 1985 in a large secondary branch of the River Danube at Budapest at river km 1,653 (THURÁNSZKY and FORRÓ, 1987). In 1991, O. limosus was detected at Dunaföldvár, approximately 90 km downstream 
A

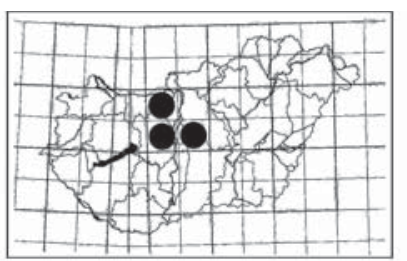

$\mathrm{D}$

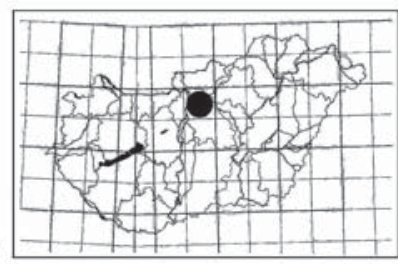

B

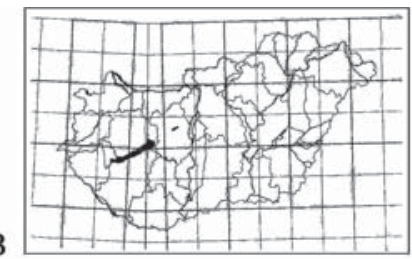

E

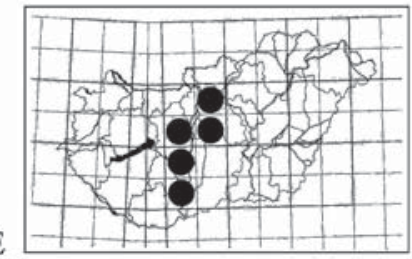

C
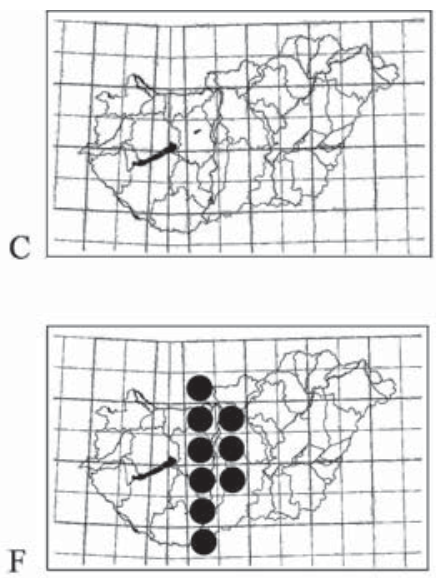

Figure 1

$50 \mathrm{~km} \times 50 \mathrm{~km}$ UTM distribution of Orconectes limosus in Hungary between 1950 and 2005 (the edge of the squares represent $50 \mathrm{~km}$ ). Empty square: no data; solid circle: data available. A: 1950s, B: 1960s, C: 1970s, D: 1980s, E: 1990s, F: 2000s (Note that unlike what is plotted in map A-E, map $F$ represents only half a decade.).

\section{Figure 1}

Distribution $50 \mathrm{~km} \times 50 \mathrm{~km}$ UTM d'Orconectes limosus en Hongrie entre les années 1950 et le années 2000 (la taille des carrés représentent $50 \mathrm{~km}$ ). Carrés vides : aucune donnée ; Cercles pleins : données disponibles. A : années 1950, B : années 1960, C : années 1970, D : années 1980, E : années 1990, F : années 2000 (noter que contrairement aux cartes A-E, cette période représente moins de la moitié d'une décennie.).

(NESEMANN et al., 1995). By 1998, it had reached the Gemenc section of the river (river $\mathrm{km} \mathrm{1,481),} 172 \mathrm{~km}$ downstream of the first observations (PUKY, 2000), by 2001 it was also recorded from Mohács (Gábor CSÖRGITS, Tamás DEME, pers. comm.). During its colonisation of the Carpathian Basin O. limosus also got into Croatia from Hungary. It was found there at Kopácsi rét/Kopacki rit (MAGUIRE and KLOBUCAR, 2003), a floodplain area approximately $25 \mathrm{~km}$ upstream from the mouth of the River Dráva, which reaches the

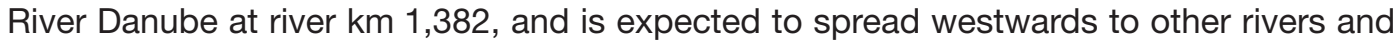
lakes (LAJTNER et al., 2005).

On the basis of the available records from the past 20 years in Hungary, the colonisation speed of $O$. limosus was calculated to be more than $13 \mathrm{~km} \mathrm{yr}^{-1}$ (varying between 11.7 and $15 \mathrm{~km} \mathrm{yr}^{-1}$ over shorter sections), but if its presence at Kopácsi rét/ Kopacki rit in Croatia is also taken into consideration, it is over $16 \mathrm{~km} \mathrm{yr}^{-1}$. This pace can

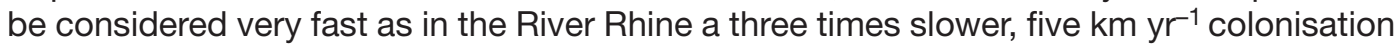
speed was reported in the 1960s (SCHWENG, 1968). It is unknown, however, if the rapid spread of $O$. limosus along the Hungarian Danube stretch was helped by deliberate introductions. Several authors suggested earlier that unknown translocation by boat traffic on the River Danube can be how an isolated population was formed in the Ölhafen, in the southeastern part of Vienna (NESEMANN et al., 1995; PÖCKL, 1999a, 1999b) and this factor could certainly influence the colonisation of the Hungarian Danube stretch. However, at present no such evidence exists for Hungary. If $O$. limosus spreads with the same speed among other waters, the colonisation of Lake Balaton and upstream sections of the River Dráva belonging to Hungary is to be expected within 2-5 and 5-10 years, respectively. 
The colonisation pattern of $O$. limosus varies between different European countries. Besides the main arm and side arms of the River Danube, abundant and spreading populations have been found in other connected waters such as the Szõdrákos-stream and the Sió canal (PUKY, 2000, 2004) as well as the River Ipoly and lowland canals in the Great Hungarian Plain (KOVÁCS et al., 2005) in Hungary. It is similar to the situation in several other European lowland countries and areas, such as the Netherlands (ADEMA, 1989), northeastern Germany and northwestern Poland (SCHULZ and ŚMIETANA, 2001), where $O$. limosus has become predominant. What is more, in many regions of Poland it is also the only crayfish species present and as such it has even become the commonest prey of fish such as Silurus glanis or other piscivorous fish in certain life stages (CZARNECKI et al., 2003). It is partly due to the fact, that, unlike e.g. A. astacus, O. limosus is not sensitive to land use changes and human activities (SCHULZ et al., 2002). In other, more mountainous or hilly regions, such as Austria, Switzerland or the western part of the Czech Republic it is mainly restricted to large running waters such as the River Danube, Elbe or Morava (PETRUSEK et al., 2006; HEFTI, 2006; PÖCKL and PEKNY, 2002). In large rivers, where the habitat diversity, discharge and current velocity is high and crayfish density is low, native species can coexist with O. limosus (PÖCKL and PEKNY, 2002) but even in the Czech Republic, however, this species is the main potential vector of Aphanomyces astaci, which was also proved by recent (1998-99 and 2004) outbreaks of crayfish plague in smaller brooks and rivers, and a subsequent investigation also proved a high ratio of infected individuals in different populations (KOZUBIKOVÁ et al., 2005). As such, it also means a potential threat to native crayfish species in Hungary, too. Fortunately, however, even if $O$. limosus was spreading fast along the Hungarian Danube stretch, there is a hope that it will not enter into certain habitats. In the detailed investigation of the floodplain of the River March/Morava in Austria it was never found in backwaters, old meanders and oxbow lakes (PÖCKL and PEKNY, 2002). Similarly, PETRUSEK et al. (2006) detected in the Czech Republic that in smaller streams it usually stayed in lower reaches and did not penetrate far upstream. This is in accordance with our findings that even if $O$. limosus is present in the neighbouring Danube stretch for nearly 15 years, it has not been recorded entering mountain streams in the Danube Bend. As those are the main habitats of $A$. torrentium in Hungary, this finding has important applications for the conservation of that native species, i.e. most of those efforts should be focussed on habitat improvement and possible (re)introductions. However, the regular (3-5 year) checking of those habitats for the presence of $O$. limosus is also advisable. If $O$. limosus will spread with the same speed and distribution pattern in the Carpathian Basin, mid-term it should colonise large rivers such as the River Tisza, their lowland tributaries and canals. Especially in smaller water flows it will probably be a significant threat to $A$. astacus populations e.g. in the southern part of Transdanubia, where this phenomenon is likely to occur soon, and their elimination is a real possibility. As a consequence, the current distribution of decapod species in that geographical region and the regular monitoring of future changes are urgent conservation tasks, which has not not only national but also regional importance.

\section{ACKNOWLEDGEMENTS}

The authors thank Gábor Csörgits, Tamás Deme, Tibor Erős, Dr. János Nosek, Dr. Nándor Oertel and Balázs Tóth for providing data, Dr. Tibor Kovács for sharing information from an accepted paper before its publication, Dr. Julian Reynolds and Dr. Premyslav Śmietana for their valuable comments on an earlier version of the manuscript, Dr. Julian Reynolds for improving the English text and Dr. Catherine SoutyGrosset for the French translation.

\section{REFERENCES}

ALDRIDGE D.C., ELLIOTT P., MOGGRIDGE G.D., 2004. The recent and rapid spread of zebra mussel (Dreissena polymorpha) in Great Britain. Biol. Cons., 119, 253-261. 
ADEMA J.P.H.M., 1989. De verspreiding van rivierkreeften in Nederland. Niewsbrief European Invertebrate Survey, Nederland. 19, 3-10.

CALLAGHAN T.P., KARLSON R.H., 2002. Summer dormancy as a refuge from mortality in the freshwater bryozoan Plumatella emarginata. Oecologia (Berlin), 132, 51-59.

CSÁNYI B., JUHÁSZ P., TYAHUN SZ., 2002. A Ráckevei-Soroksári-Duna makroszkopikus vízi gerincteleneinek vizsgálata. Vízügyi Közlemények., LXXXIV(2): 173-193.

CZARNECKI M., ANDRZEJEWSKI W., MASTYNSKI J., 2003. The feeding selectivity of wels (Silurus glanis L.) in Lake Goreckie. Archiwum Rybactwa Polskiego, 11, 141147.

CZERNIEJEWSKI P., FILIPIAK J., 2001. Krab welnistoszczypcy (Eriocheir sinensis Milne Edwards 1853) z Zalewu Szczecinskiego. Komunikaty Rybacki., 1, 28-31.

HEFTI D., 2006. Crayfish management for Swiss waters. In: GHERARDI F. and SOUTYGROSSET C., 2005: European crayfish as heritage species-linking research and management strategies to conservation and socio-economic development, CRAYNET, Volume 4, Bull. Fr. Pêche Piscic., 380-381, 938-951.

HOBBS H.H., JASS J.P., HUNER J.V., 1989. A review of global crayfish introductions with particular emphasis on two North American species (Decapoda, Cambaridae). Crustaceana, 56, 299-316.

HOLDICH D.M., 2002. Distribution of crayfish in Europe and some adjoining countries. In: SOUTY-GROSSET C., GRANDJEAN F. (eds) Knowledge-based management of European native crayfish. Crayfish special, Volume 4. Bull. Fr. Pêche Piscic., 367, 611-650.

GRATTON C., DENNO R.F., 2005. Restoration of arthropod assemblages in a Spartina salt marsh following the removal of the invasive plant Phragmites australis. Restoration Ecology, 13, 358-372.

KLOCKER C.A., STRAYER D.L., 2004. Interactions among an invasive crayfish (Orconectes rusticus), a native crayfish (Orconectes limosus), and native bivalves (Sphaeridae and Unionidae). Northeastern Naturalist, 11, 167-178.

KOVÁCS T., JUHÁSZ P. AMBRUS A., 2005. Adatok a Magyarországon élő folyami rákok (Decapoda: Astacidae, Cambaridae) elterjedéséhez (Data to the distribution of crayfish in Hungary (Decapoda: Astacidae, Cambaridae)). Folia Historico-naturalia Musei Matraensis, 29, in press.

KOZUBIKOVÁ É., PETRUSEK A., DURIS Z., KOZÁK P., GEIGER S., HOFFMANN R., OIDTMANN B., 2005. Detection of the crayfish plague fungus Aphanomyces astaci in the Czech Republic. In: GHERARDI F. and SOUTY-GROSSET C., 2005: European crayfish as heritage species-linking research and management strategies to conservation and socio-economic development, CRAYNET, Volume 4, Bull. Fr. Pêche Piscic., 380-381, 1314-1325.

LAJTNER J., KLOBUCAR G. I. V., MAGUIRE I., LUCIC A., STAMBUK A., ERBEN R., 2005. They came from the Danube River - History and present status of Dreissena polymorpha and Orconectes limosus in Croatia. Biological Invasions in inland waters, Firenze, Italy, May 5-7, 2005, Abstracts, p. 46.

MAGUIRE I., KLOBUCAR G., 2003. Appearance of Orconectes limosus in Croatia. Crayfish News, 25(3), 7.

MILLS M. D., RADER R. B., BELK M. C., 2004. Complex interactions between native and invasive fish: the simultaneous effects of multiple negative interactions. Oecologia, $141,713-721$. 
NESEMANN H., PÖCKL M., WITTMANN K. J., 1995. Distribution of epigean Malacostraca in the middle and upper Danube (Hungary, Austria, Germany). Miscellanea Zoologica Hungarica, 10, 49-68.

PAUNOVIC M., CAKIC P., HEGEDIS A., KOLAREVIC J., LENHARDT M., 2004. A report of Eriocheir sinensis ( $\mathrm{H}$. Milne Edwards, 1854) [Crustacea: Brachyura: Grapsidae] from the Serbian part of the Danube River. Hydrobiologia, 529, 275-277.

PETRUSEK A., FILIPOVÁ L., DURIS Z., HORKÁ I., KOZÁK P., POLICAR T., STAMBERGOVÁ M., KUCERA Z., 2006. Distribution of the invasive spiny-cheek crayfish (Orconectes limosus) in the Czech Republic: history and present. In: GHERARDI F. and SOUTYGROSSET C., 2005: European crayfish as heritage species-linking research and management strategies to conservation and socio-economic development, CRAYNET, Volume 4. Bull. Fr. Pêche Piscic., 380-381, 903-918.

PÖCKL M., 1999a. Distribution of crayfish species in Austria with special reference to introduced species. Freshwater Crayfish, 12, 733-750.

PÖCKL M., 1999b. The distribution of native and introduced species of crayfish in Austria. Freshwater Forum, 12, 4-17.

PÖCKL M., PEKNY R., 2002. Interaction between native and alien species of crayfish in Austria: case studies. In: SOUTY-GROSSET C., GRANDJEAN F. (eds) Knowledgebased management of European native crayfish. Crayfish special, Volume 4. Bull. Fr. Pêche Piscic., 367, 763-776.

PUKY M., 2000. Distribution of Decapoda species along the Hungarian Danube section and some tributaries with special emphasis on their conservation status. Limnological Reports, 33, 285-290.

PUKY M., 2004. Zoological mapping along the Hungarian lower Danube: Importance, aims and necessity discussed with the example of three unrelated groups, Decapoda, Amphibia and Reptilia. Limnological Reports, 35, 613-618.

PUKY M., REYNOLDS J.D., SCHÁD P., 2005. Native and alien Decapoda species in Hungary: distribution, status, conservation importance. Bull. Fr. Pêche Piscic., 376377, 553-568.

RABITCH W., SCHIEMER F., 2003. Chinesische Wollhandkrabbe (Eriocheir sinensis) in der österreichischen Donau festgestellt. Österreichische Fischerei, 56, 61-65.

SCHULZ H.K., ŚMIETANA P., SCHULZ R., 2002. Crayfish occurrence in relation to landuse properties: implementation of a Geographic Information System. In: SOUTYGROSSET C., GRANDJEAN F. (eds) Knowledge-based management of European native crayfish. Crayfish special, Volume 4. Bull. Fr. Pêche Piscic., 367, 861-872.

SCHULZR., ŚMIETANA P., 2001. Occurrence of native and introduced crayfish in northeastern Germany and northwestern Poland. Bull. Fr. Pêche Piscic., 361, 629-641.

ŚMIETANA P., 2004. Active protection of native crayfish in Poland. In: TAUGBØL T. and SOUTY-GROSSET C., 2004: European native crayfish with a special focus on Astacus astacus: linking socioeconomics and conservation, CRAYNET, Volume 2, Bull. Fr. Pêche Piscic., 372-373, 289-299.

SCHWENG E., 1968. Die Amerikanische Flusskrebs Orconectes limosus (Rafinesque) im Rhein. Mainzer Naturwiss. Arch., 7, 265-274.

THURÁNSZKY Z., 1960. A ráktelepítésrõl se feledkezzünk meg! Halászat, 7, 37.

THURÁNSZKY M., FORRÓ L., 1987. Data on distribution of freshwater crayfish (Decapoda: Astacidae) in Hungary in the late 1950s. Miscellanea Zoologica Hungarica, 4, 6569. 
